\title{
PHARMACEUTICAL AND ANALYTICAL STUDY ON LOHA BHASMA
}

\author{
Rajendraprasad $\mathrm{ML}^{1}$, Shruti Shekhar ${ }^{2}$ Subramanya $\mathrm{AR}^{3}$
}

\begin{abstract}
Rasashastra is a subject which deals with metals and its therapeutic effect. It mentions the use of metals in a refined form as bhasma. Loha is used extensively in the Ayurvedic literature for the management of various diseases like Pandu (Anemia), Shotha (Oedema), Kamala (Jaundice) etc. It is very hard metal hence it should be made into bhasma for using it for medicinal purposes. Iron fillings are subjected to samamnya shodhana and vishesha shodha to prepare the bhasma. Pharmaceutical and analytical studies were conducted during the process of preparation of the Loha bhasma to know the changes in the chemical composition at various satges. Namburi Phased Spot Test was done to prove the fineness of the bhasma. In this study an attempt has been made to standardize the process of the preparation of the Loha bhasma and to establish chemical standards like iron content in the bhasma and the Namburi Phased Spot Test.
\end{abstract}

Key words: Loha, Trivida paka, Loha bhasma, Qualitative \& Quantitative analysis.

\section{Introduction:}

The basic purpose of this science is to keep the human beings free from disease, old age \& death. Rasashastra is one of the branches of Ayurveda which has a rich knowledge of mineral and metallic preparations. The minerals and metals were used in the form of Rajah (mineral waste during the processing of the minerals and metals). During the $8-9^{\text {th }}$ century A.D, the Ayurvedics, Siddhas, Nath yogis and the Tantrikas developed the medicinal uses of metals and minerals which ultimately attained the name Rasashastra or Rasatantra.

Rasashastra is a subject which deals with metals and its therapeutic effect. It mentions the use of metals in a refined form as bhasma. Their use reduced the quantity of the dose administered and increased the palatability, tissue availability and shelf-life of the drugs.

Loha is used extensively in the Ayurvedic literature for the management of various diseases like Pandu (Anemia),
Shotha (Oedema), Kamala (Jaundice) etc. It is very hard metal. In the samhitas it was mentioned to use it in the form of powder. But in the texts of Rasasastra loha is mentioned in the form of shodhita bhasma (Purified form of bhasma) for the medicinal uses. Administration of impure form of the Loha leads to many medical problems which may damage the kidneys, liver etc. This can be achieved by shodhana followed by Trivida paka (Sthali paka, Bhanu paka and Puta paka) to convert Loha into Bhasma. To know the changes that occur after shodhana, Trivida paka of loha \& also to bring to the lime light the pharmaceutical \& analytical changes that occur during preparation of Loha bhasma this study is intended.

\section{Aims and objectives: \\ * To conduct shodhana of Loha \\ * To conduct Trivida Paka of Loha in order to prepare Lohabhasma}

1*. Corresponding author: Lecturer, Department of Rasashastra, JSS Ayurveda Medical College, Mysore, Karnataka, India, Tel: +919845817721, E.mail: prasad.rajendra150@gmail.com

2. Physician, Amruta Health Clinic, Dr. Rajkumar Road, Near Teresian College Circle, Mysore, 3. Chief Consultant, Ganesh Consultancy and analytical services, Mysore. 
* Physical \& chemical Analysis of Lohabhasma in different stages of shodhana and preparation of bhasma.

\section{Materials and methods:}

Selection of Raw Materials:-

Loha collected from Sri Venkatesha

Engineering Works', Gandhi Square, Mysore, by identifying the Grahyalakshanas of Loha mentioned in the classics.

\section{Methods:}

Preparation of the Loha bhasma involves two stages.

1. Shodhana

2. Trividha paka

Shodhana: (RRS 5/29)

This is of two types. Samanya shodhana and Vishesha shodhana.

\section{Samanya shodhana:}

Materials: Loha - 1, 500 gm, Tila Taila - $7000 \mathrm{ml}$, Takra - $7000 \mathrm{ml}$, Gomutra - 7000 ml, Kanji - 7000 ml, Kulatha Kwatha - 7000 ml

Instruments: Steel Vessels, Cloth, Gas Stove, Big Iron pan, Stirrer

Method: $1500 \mathrm{gm}$ of Loha is heated until it become red hot \& immediately it is quenched into 1000 $\mathrm{ml}$ of Tila taila kept in a wide mouthed vessel \& left for $5 \mathrm{~min}$ for self cooling. After self cooling of Loha, it is taken out and again heated till red hot and again quenched in taila. Each time the taila or the liquid used should be changed. This procedure is called as Nirvapa and it is repeated for 7 times each in Taila, takra, Gomutra, Kanji and Kulatha kwatha.

Vishesha shodhana: (R.R.S 5/102-103).

It is also similar in procedure to the samanya shodhana but the drava dravya should be Triphala kwatha. And the nirvapa is done in Triphala kwatha for 7 times.

\section{Trivida Paka of Loha:}

After the shodhana process, loha is subjected to trividha paka. This includes Banupaka, Sthalipaka and Putapaka.
Banupaka: (RSS 1/302-304)

Materials: Loha- 500 gm, Triphala

Kashaya Curna

Instruments: Steel plate

Method: 500 grams of Shuddha Loha was taken in steel plate. 500 grams of Triphala kashaya Churna was taken in steel Vessel, to this 2 times water was added \& kept on Mandagni. It was boiled until it reduces to $1 / 4$ th. After preparation of Triphala kwatha it was put into steel plate which contains Shuddha Loha. This was exposed to sunlight \& left it until it dries completely. This procedure was repeated for 3 times.

Sthalipaka: (RSS1/309-310) This is done after banupaka.

Materials: Mula of Palasha, Eranda, Shatavari \& Panchanga of Bringaraja - together 500 gm; Loha: 500 gm

Instruments: Steel Vessel

Method: In a vessel 500 grams of Loha was taken which has undergone Banupaka and the kwatha, prepared by Palasha, Eranda, Shatavari mula and Bringaraja, was added \& boiled in sthali (dish), until kwatha was evaporated completely. This was repeated for 3 times.

Putapaka: (RSS 1/343)

Materials: - Loha which was undergone Shodhana, Banupaka \& Sthalipaka - 200 grams (coarse powder)

Shudha Hingula, Kumari

Instruments: - Khalva yantra, Earthen sharavas, Multani soil, Cow dung cakes - 1,000

Method: Shuddha Hingula was taken in Khalwa \& made into fine powder. To these 12 parts of Shudha Loha curna was added \& mardana was done to mix properly. After that this was given bhavana with Kumari \& chakrikas were prepared and dried. These dried chakrikas are kept in Sharava \& Sandhibandhana was done properly using multani soil. Then again the sharava was kept for drying. After drying, 700 cowdung cakes was arranged in pit and the Sharava was kept on it. Then it is 
covered by 300 more cowdung cakes. Then the cowdung cakes are ignited. After the complete burning and self cooling of the kiln the sharava samputa is taken out and opened. The charred chakrikas are collected, ground and again the same procedure is repeated for 7 times to get Loha bhasma. After completion of puta paka process, Loha bhasma was collected $\&$ made into fine $\&$ smooth by grinding.

Assessment criteria:

The proper formation of the Loha bhasma is assessed both in Ayurvedic and analytical ways. Ayurvedic tests for the bhasma are Apunarbhava and Nirutta bhasma. Analytical tests conducted are Namburi Phased Spot.

\section{Observation and results:}

Table 1: Showing observations made during the Shodhana of Loha.

Table 1: Nirvapa with Taila

\begin{tabular}{|c|c|c|c|c|}
\hline Nirvapa & Dravya & $\begin{array}{c}\text { Duration of } \\
\text { heat (in min) }\end{array}$ & Colour after nirvapa & $\begin{array}{c}\text { Quantity of Loha } \\
\text { reduced (in gm) }\end{array}$ \\
\hline 1 & Tila Taila & $50 \mathrm{~min}$ & Ad. Grey & Nil \\
\hline 2 & Tila Taila & $45 \mathrm{~min}$ & Ad. Grey & Nil \\
\hline 3 & Tila Taila & $45 \mathrm{~min}$ & Ad. Grey & Nil \\
\hline 4 & Tila Taila & $45 \mathrm{~min}$ & Ad. Grey & 2 \\
\hline 5 & Tila Taila & $40 \mathrm{~min}$ & Ad. Grey & 2 \\
\hline 6 & Tila Taila & $40 \mathrm{~min}$ & Ad. Grey & $4 \mathrm{gms}$ \\
\hline 7 & Tila Taila & $40 \mathrm{~min}$ & Ad. Grey & \\
\hline
\end{tabular}

Table 2: Nirvapa with Takra

\begin{tabular}{|l|l|l|l|l|}
\hline Nirvapa & Dravya & $\begin{array}{c}\text { Duration of heat (in } \\
\text { min) }\end{array}$ & \multicolumn{1}{|c|}{$\begin{array}{c}\text { Colour after } \\
\text { nirvapa }\end{array}$} & \multicolumn{1}{|c|}{$\begin{array}{c}\text { Quantity of Loha reduced } \\
\text { (in gm) }\end{array}$} \\
\hline 1 & Takra & $50 \mathrm{~min}$ & Ad Grey & Nil \\
\hline 2 & Takra & $45 \mathrm{~min}$ & Ad Grey & Nil \\
\hline 3 & Takra & $45 \mathrm{~min}$ & Ad Grey & Nil \\
\hline 4 & Takra & $40 \mathrm{~min}$ & Ad Grey & Nil \\
\hline 5 & Takra & $40 \mathrm{~min}$ & Ad Grey & 2 \\
\hline 6 & Takra & $40 \mathrm{~min}$ & Ad Grey & 4 \\
\hline 7 & Takra & $40 \mathrm{~min}$ & Ad Grey & 4 \\
\hline
\end{tabular}

Table 3: Nirvapa with Gomutra

\begin{tabular}{|c|c|c|c|c|}
\hline Nirvapa & Dravya & $\begin{array}{c}\text { Duration of heat (in } \\
\text { min) }\end{array}$ & $\begin{array}{c}\text { Colour after } \\
\text { nirvapa }\end{array}$ & $\begin{array}{c}\text { Quantity of Loha reduced } \\
\text { (in gm) }\end{array}$ \\
\hline 1 & Gomutra & $50 \mathrm{~min}$ & Ad. Grey & Nil \\
\hline 2 & Gomutra & 45 & Ad. Grey & Nil \\
\hline 3 & Gomutra & 45 & Ad. Grey & 2 \\
\hline 4 & Gomutra & 40 & Ad. Grey & 2 \\
\hline 5 & Gomutra & 40 & Ad. Grey & 2 \\
\hline 6 & Gomutra & 40 & Ad. Grey & 4 \\
\hline 7 & Gomutra & 40 & Ad. Grey & \\
\hline
\end{tabular}


Table 4: Nirvapa with Kanji

\begin{tabular}{|c|c|c|c|c|}
\hline Nirvapa & Dravya & $\begin{array}{c}\text { Duration of heat (in } \\
\text { min) }\end{array}$ & $\begin{array}{c}\text { Colour after } \\
\text { nirvapa }\end{array}$ & $\begin{array}{c}\text { Quantity of Loha reduced } \\
\text { (in gm) }\end{array}$ \\
\hline 1 & Kanji & $50 \mathrm{~min}$ & Ad. Grey & Nil \\
\hline 2 & Kanji & 45 & Ad. Grey & Nil \\
\hline 3 & Kanji & 40 & Ad. Grey & 4 \\
\hline 4 & Kanji & 40 & Ad. Grey & 2 \\
\hline 5 & Kanji & 40 & Ad. Grey & 2 \\
\hline 6 & Kanji & 40 & Ad. Grey & 2 \\
\hline 7 & Kanji & 40 & Ad. Grey & \\
\hline
\end{tabular}

Table 5: Nirvapa with Kulatha Kwatha

\begin{tabular}{|c|c|c|c|c|}
\hline Nirvapa & Dravya & $\begin{array}{c}\text { Duration of heat (in } \\
\text { min) }\end{array}$ & $\begin{array}{c}\text { Colour after } \\
\text { nirvapa }\end{array}$ & $\begin{array}{c}\text { Quantity of } \\
\text { Loha reduced } \\
\text { (in gm) }\end{array}$ \\
\hline 1 & Kulatha Kwatha & $50 \mathrm{~min}$ & Ad. Grey & Nil \\
\hline 2 & Kulatha Kwatha & 45 & Ad. Grey & Nil \\
\hline 3 & Kulatha Kwatha & 45 & Ad. Grey & Nil \\
\hline 4 & Kulatha Kwatha & 40 & Ad. Grey & 4 \\
\hline 5 & Kulatha Kwatha & 40 & Ad. Grey & 2 \\
\hline 6 & Kulatha Kwatha & 40 & Ad. Grey & 2 \\
\hline 7 & Kulatha Kwatha & 40 & Ad. Grey & 2 \\
\hline
\end{tabular}

Table 6: Banupaka of Loha

\begin{tabular}{|c|c|c|c|c|}
\hline Nirvapa & Dravya & $\begin{array}{c}\text { Duration of } \\
\text { heat (in min) }\end{array}$ & $\begin{array}{c}\text { Colour after } \\
\text { nirvapa }\end{array}$ & $\begin{array}{c}\text { Quantity of Loha } \\
\text { reduced (in gm) }\end{array}$ \\
\hline 1 & Triphala Kwatha & $5 \mathrm{hrs.}$ & Royal Blue & Nil \\
2 & Triphala Kwatha & $5 \mathrm{hrs.}$ & Royal Blue & Nil \\
3 & Triphala Kwatha & $5 \mathrm{hrs}$. & Royal Blue & Nil \\
\hline
\end{tabular}

Table 7: Sthalipaka of Loha

\begin{tabular}{|c|l|c|c|c|}
\hline Nirvapa & \multicolumn{1}{|c|}{ Dravya } & $\begin{array}{c}\text { Duration of heat } \\
\text { (in min) }\end{array}$ & $\begin{array}{c}\text { Colour after } \\
\text { nirvapa }\end{array}$ & $\begin{array}{c}\text { Quantity of Loha } \\
\text { reduced (in gm) }\end{array}$ \\
\hline 1 & $\begin{array}{l}\text { Kwatha of } \\
\text { Bringaraja, Eranda } \\
\text { mula, Shatavari, } \\
\text { Palasha mula }\end{array}$ & $25 \mathrm{~min}$ & Royal Blue & Nil \\
\hline 2 & $\begin{array}{l}\text { Kwatha of } \\
\text { Bringaraja, Eranda } \\
\text { mula, Shatavari, } \\
\text { Palasha mula }\end{array}$ & $\begin{array}{l}\text { Kwatha of } \\
\text { Bringaraja, } \\
\text { Eranda mula, } \\
\text { Shatavari, } \\
\text { Palasha mula }\end{array}$ & $25 \mathrm{~min}$ & Royal Blue \\
\hline 3
\end{tabular}




\section{Observations:}

Time taken for complete burning of cowdung cakes was 8 hrs. Loss of weight was 50 grams in 200 grams [25\%]. After 1st Puta Lohabhasma turned to brown colour. After 7th Puta Loha bhasma turned to Pakwa Jambu pala varna.

\begin{tabular}{|c|c|c|c|c|c|}
\hline $\begin{array}{c}\text { No. of } \\
\text { Times }\end{array}$ & $\begin{array}{c}\text { Drava } \\
\text { Dravya }\end{array}$ & $\begin{array}{c}\text { Duration } \\
\text { of Grinding } \\
(\mathrm{hr})\end{array}$ & $\begin{array}{c}\text { No. of } \\
\text { Cowdung } \\
\text { cakes used }\end{array}$ & $\begin{array}{c}\text { Weight reduced } \\
\text { of Lohabhasma } \\
(\mathrm{gm})\end{array}$ & $\begin{array}{c}\text { Colour change } \\
\text { of Lohabhasma }\end{array}$ \\
\hline 1 & Kumari & 3 & 1000 & 20 gms & Brown \\
2 & Kumari & 3 & 1000 & 10 & Brown \\
3 & Kumari & 3 & 1000 & 5 & Brown \\
4 & Kumari & 3 & 1000 & 5 & Brown \\
5 & Kumari & 2 & 1000 & 5 & Wild Purple \\
6 & Kumari & 2 & 1000 & 5 & Wild Purple \\
7 & Kumari & 2 & 1000 & 0 & $\begin{array}{c}\text { Pakwa Jambu } \\
\text { Pala varna }\end{array}$ \\
\hline
\end{tabular}

TEMPERATURE RECORDED OF GAJA PUTA IN LOHA BHASMA PREPARATION SHOWING IN GRAPH

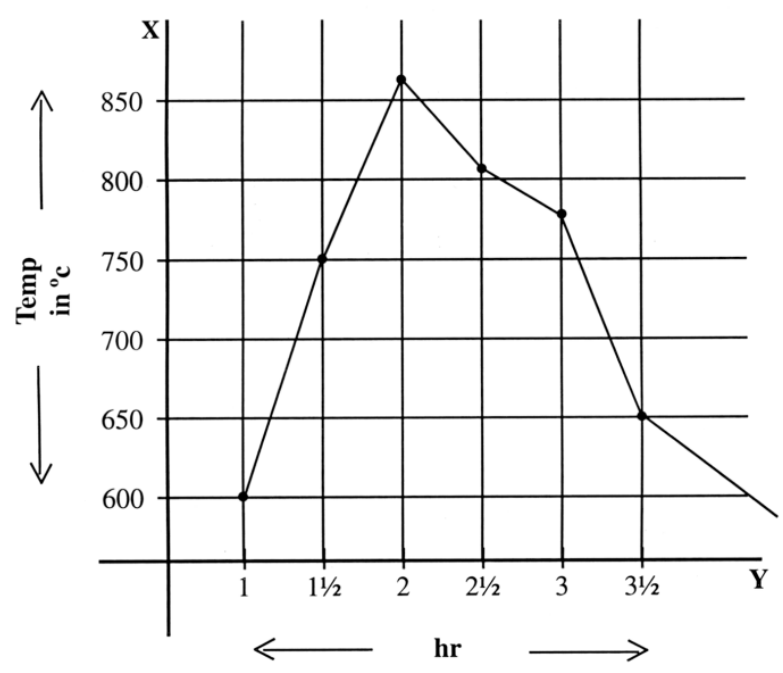

ANALYTICAL STUDY:-

Table 8: Physical Analysis of Lohabhasma

\begin{tabular}{|l|l|l|l|l|l|l|}
\hline $\begin{array}{l}\text { Sl. } \\
\text { No. }\end{array}$ & No. of Puta & Colour & Taste & Touch & Odour & Lustre \\
\hline 1 & After 1 Puta & Brown & Metallic \& Sour & Slight Rough & Pungent & More \\
\hline 2 & After 2 Puta & Brown & Metallic \& Sour & Slight Rough & Pungent & More \\
\hline 3 & After 3 Puta & Brown & $\begin{array}{l}\text { Slight Metallic } \\
\text { \& Sour }\end{array}$ & Little Smooth & Pungent & Less \\
\hline 4 & After 4 Puta & Brown & $\begin{array}{l}\text { Slight Metallic } \\
\text { \& Sour }\end{array}$ & Smooth & Pungent & Less \\
\hline
\end{tabular}




\begin{tabular}{|l|l|l|l|l|l|l|}
\hline 5 & After 5 Puta & Wild Purple & $\begin{array}{l}\text { Slight Metallic } \\
\text { \& Sour }\end{array}$ & Smooth & Pungent & No \\
\hline 6 & After 6 Puta & Wild Purple & No. Taste & Smooth & Odour less & No \\
\hline 7 & After 7 Puta & $\begin{array}{l}\text { Pakwa } \\
\text { Jambu Pala } \\
\text { varna }\end{array}$ & No. Taste & Very Smooth & Odour less & No \\
\hline
\end{tabular}

Table 9: Analysis of Physical tests of Lohabhasma

\begin{tabular}{|c|c|c|c|c|}
\hline S1. No. & No. of Puta & Varitaratwa & Uttama & Rekhapurnatwa \\
\hline 1. & After 1 Puta & Not present & Not present & Not present \\
\hline 2. & After 2 Puta & Not present & Not present & Not present \\
\hline 3. & After 3 Puta & Not present & Not present & Not present \\
\hline 4. & After 4 Puta & $\begin{array}{l}\text { Some particles are } \\
\text { floating }\end{array}$ & Not present & $\begin{array}{l}\text { Bhasma filled the } \\
\text { lines of the } \\
\text { fingers } \\
\text { felldown but } \\
\text { sometime }\end{array}$ \\
\hline 5. & After 5 Puta & $\begin{array}{l}\text { Increased floating } \\
\text { particles }\end{array}$ & Not present & $\begin{array}{l}\text { Bhasma filled the } \\
\text { lines of the } \\
\text { fingers } \\
\text { felldown but } \\
\text { sometime }\end{array}$ \\
\hline 6. & After 6 Puta & $\begin{array}{l}\text { Increased floating } \\
\text { particles }\end{array}$ & Grain did not sink & $\begin{array}{l}\text { Bhasma filled the } \\
\text { lines of the } \\
\text { fingers } \\
\text { felldown but } \\
\text { shaking }\end{array}$ \\
\hline 7. & After 7 Puta & $\begin{array}{c}\text { Most of the bhasma } \\
\text { was floating }\end{array}$ & $\begin{array}{l}\text { Grain was floating } \\
\text { but fell down after } \\
\text { shaking }\end{array}$ & $\begin{array}{l}\text { Bhasma filled the } \\
\text { lines of the } \\
\text { fingers } \\
\text { felldown but } \\
\text { shaking }\end{array}$ \\
\hline
\end{tabular}


QUANTITATIVE ANALYSIS

\begin{tabular}{|c|c|c|c|c|c|}
\hline \multicolumn{3}{|c|}{ Raw sample of Iron } & \multicolumn{3}{|c|}{ Iron After Shodhana } \\
\hline Sl. No. & PARAMETERS & RESULTS & Sl. No. & PARAMETERS & RESULTS \\
\hline 1 & Iron as $\mathrm{Fe}$ & $96.82 \%$ & 1 & Iron as $\mathrm{Fe}$ & $96.80 \%$ \\
\hline 2 & Manganese as $\mathrm{Mn}$ & $0.83 \%$ & 2 & Manganese as Mn & $0.82 \%$ \\
\hline 3 & Chromium as $\mathrm{Cr}$ & $1.03 \%$ & 3 & Chromium as $\mathrm{Cr}$ & $1.02 \%$ \\
\hline 4 & Carbon as $\mathrm{C}$ & $0.25 \%$ & 4 & Carbon as $\mathrm{C}$ & $0.23 \%$ \\
\hline 5 & Silicon as $\mathrm{Si}$ & $0.22 \%$ & 5 & Silicon as $\mathrm{Si}$ & $0.235 \%$ \\
\hline 6 & Nickel as $\mathrm{Ni}$ & $0.32 \%$ & 6 & Nickel as $\mathrm{Ni}$ & $0.39 \%$ \\
\hline 7 & Phosphorus as $\mathrm{P}$ & $0.02 \%$ & 7 & Phosphorus as $\mathrm{P}$ & $0.016 \%$ \\
\hline 8 & Sulphur as S & $0.08 \%$ & 8 & Sulphur as S & $0.07 \%$ \\
\hline 9 & Molybdenum as Mo & $0.15 \%$ & 9 & Molybdenum as Mo & $0.14 \%$ \\
\hline 10 & Magnesium as $\mathrm{Mg}$ & $0.08 \%$ & 10 & Magnesium as $\mathrm{Mg}$ & $0.08 \%$ \\
\hline 11 & Calcium as $\mathrm{Ca}$ & $0.05 \%$ & 11 & Calcium as $\mathrm{Ca}$ & $0.09 \%$ \\
\hline 12 & Potassium as $\mathrm{K}$ & $0.06 \%$ & 12 & Potassium as $\mathrm{K}$ & $0.05 \%$ \\
\hline 13 & Sodium as $\mathrm{Na}$ & $0.08 \%$ & 13 & Sodium as $\mathrm{Na}$ & $0.04 \%$ \\
\hline \multicolumn{3}{|c|}{ After Banupaka \& Sthalipaka } & \multicolumn{3}{|c|}{ After Puta Paka } \\
\hline Sl. No. & PARAMETERS & RESULTS & Sl. No. & PARAMETERS & RESULTS \\
\hline 1 & Iron as $\mathrm{Fe}$ & $96.67 \%$ & 1 & Silica as $\mathrm{SiO}_{2}$ & $9.07 \%$ \\
\hline 2 & Manganese as Mn & $0.75 \%$ & 2 & Iron as $\mathrm{Fe}_{2} \mathrm{O}_{3}$ & $89.48 \%$ \\
\hline 3 & Chromium as $\mathrm{Cr}$ & $1.11 \%$ & 3 & Calcium as $\mathrm{CaO}$ & $0.11 \%$ \\
\hline 4 & Carbon as $\mathrm{C}$ & $0.22 \%$ & 4 & Magnesium as $\mathrm{MgO}$ & $0.88 \%$ \\
\hline 5 & Silicon as $\mathrm{Si}$ & $0.29 \%$ & 5 & Sodium as $\mathrm{Na}_{2} \mathrm{O}$ & $1.01 \%$ \\
\hline 6 & Nickel as $\mathrm{Ni}$ & $0.44 \%$ & 6 & Potassium as $\mathrm{K}_{2} \mathrm{O}$ & $0.17 \%$ \\
\hline 7 & Phosphorus as $\mathrm{P}$ & $0.015 \%$ & 7 & Chlorides as $\mathrm{Cl}$ & $0.05 \%$ \\
\hline 8 & Sulphur as S & $0.06 \%$ & 8 & Sulphates as $\mathrm{SO}_{4}$ & $0.02 \%$ \\
\hline 9 & Molybdenum as Mo & $0.15 \%$ & 9 & Ash Value & $98.24 \%$ \\
\hline 10 & Magnesium as $\mathrm{Mg}$ & $0.08 \%$ & 10 & Water Soluble & $1.56 \%$ \\
\hline 11 & Calcium as $\mathrm{Ca}$ & $0.09 \%$ & 11 & Water insoluble & \\
\hline 12 & Potassium as $\mathrm{K}$ & $0.05 \%$ & 12 & Acid Soluble & $98.44 \%$ \\
\hline 13 & Sodium as $\mathrm{Na}$ & $0.04 \%$ & 13 & Acid insoluble & \\
\hline
\end{tabular}

QUALITATIVE ANALYSIS: - 1. Apunarbhava Test, 2. Nirutta Test, 3. Namburi Phased Spot Test

\section{APUNARBHAVA TEST OF LOHA BHASMA}

5 grams of loha bhasma was mixed with 5 grams of Mitrapanchaka and kept in sharava and sandhibandana was done. This was subjected to gajaputa. After Swangasheeta it was colleted.

Observation:- Absence of shining particles, this indicates there was no free metal \& hence passed Apunarbhava test

I. NIRUTTA TEST OF LOHA BHASMA: - 1 gram of loha bhasma was mixed with 1 gram of Shudda Rajata individually, kept in sharava and 
sandibandana was done and subjected to gajaputa. After Swangasheeta it was collected.

OBSERVATION: - Weight of Shudda Rajata was same after puta. This indicates loha bhasma not mixed with rajata and hence passed nirutta bhasma pareeksha.

\section{NAMBURI PHASED SPOT TEST (N.P.S.T)}

Chromotography is relatively a new technique which was first invented by M. Tswett, a botonist in 1906, for the sepration of coloured substances into individual components. Since then, the technique has undergone tremendous modifications so that now a days various types of chromotographies are in use to separate almost any given mixture, whether coloured (or) colour less, into its constituents and to test the purity of these constituents. Paper chromatography one of the varieties of chromotographies in a special case of partition chrmotography in which the absorbent column in a paper strip. Namburi phased spot test (N.P.S.T.) is known as circular paper chromatography (variety of paper chromatography) which is called also radial paper chromatography. N.P.S.T. was introduced by Dr. Namburi Hanumantha Ro in the year 1970. The author has taken up the project of quality control of bhasmas and sinduras along with other projects to meet the challenges thrown both by the public and press about 32 years back.

Definition of N.P.S.T.:- When a drop of clear solution of a substance that is under examination is put on one of the chemical reacting papers, a spot with a series of changes in colour and pattern will appear. It is the sludy of this spot and colour at three successive phases spreading over three different time intervals in known as the "phased spot test".

Advantages of N.P.S.T.:- This technique is very helpful for quality assessment of bhasmas as per the standards of Rasasasthra. The study of differential identification of various bhasmas is made possible by N.P.S.T. This test has an advantage of measuring the sensitivity of reactions at different time intervals. This is a method to study or detect continual chemical changes (reaction) that take place gradually between two chemical substances on static media at very second or even at a fraction of a second. Some initial (or) intermediate reactions (or) changes which occur before culminating it to a major chemical reaction can be detected by the present technique.

\section{N.P.S.T. OF LOHA BHASMA:-}

Sample used for Present study: 0.25 gms (Loha Bhasma)

Chemical used in the study: $5 \% \mathrm{HCl} \mathrm{V/c}$, $2.5 \%$ potassium ferrocynide paper.

Equipments: Test tube holder, Test tube stand, three test tubes, $5 \mathrm{ml}$ Graduated pipette, Bunsen burner, Dropper.

Procedure: - 0.25 gms of sample was taken into test tubes. Test tube was heated till the bottom appears and with the help of Bunsen burner \& it was allowed to self cool for some time $0.5 \mathrm{ml}$ of $5 \% \mathrm{HCl}$ was taken in a graduated pipette and slowly dropped in the test tube. Now again test tube was heated for a while. The sample was allowed to stay for 24 hours without shaking. Two hours before treating with a chemical reaction paper, the test tube was shaken and kept as it. Then a drop of supernatant (clear) solution of sample was dropped on the $2.5 \%$ potassium ferrocyanide paper with the help of dropper carefully. No sooner the drop came in contact with the $2.5 \%$ potassium ferro cyanide paper an instantaneous characteristic spot began to form \& changes rapidly \& continually for some time.

Observations: - I Phase: The first phase of reaction extends from the very movement of formation of spot till the end 
of 5th minute. This phase is called "Immediate reaction". II Phase: The second phase of reaction extends there after upto 20th minute. This phase is called "Delayed reaction". III Phase: The third phase extends from end of 20th minute to 24 th hour or above. This phase is called as "Late reaction".

\begin{tabular}{|l|l|l|l|}
\hline Sl.no & I Phase & II phase & $\begin{array}{l}\text { III } \\
\text { phase }\end{array}$ \\
\hline 1 & $\begin{array}{l}\text { Central } \\
\text { Deep Blue } \\
\text { spot with } \\
\text { light blue, } \\
\text { white } \\
\text { colour and } \\
\text { brown thin } \\
\text { circles in } \\
\text { periphery }\end{array}$ & $\begin{array}{l}\text { Expanded } \\
\text { blue spot }\end{array}$ & $\begin{array}{l}\text { No } \\
\text { other } \\
\text { changes }\end{array}$ \\
\hline
\end{tabular}

\section{DISCUSSION: -}

The iron fillings used in the study can be compared with the teekshna loha. This metal is used for to make sharp instruments, bolts etc. As the metal is very hard it is made into powder form by making it into the bhasma. This can be achieved by subjecting iron to samanya and vishesha shodhana procedures. The two procedures were done according to the classical literature available.

Physical and chemical analysis was carried out at various stages of preparation of the drug purification, such as Analysis of the raw material (Iron), Analysis of Iron after samanaya and vishesha shodhana and Analysis of completely formed loha bhasma was analyzed chemically for percentage of Iron \& other metals. Iron was $96.82 \%$ in steel chip. After samanya $\&$ vishesha shodhana, only $0.2 \%$ of Iron was reduced. There were no much changes in chemical analysis. After Banupaka \& sthali paka $2 \%$ of Iron was reduced. It was in $\mathrm{Fe}$ form only. After puta paka, Iron was $89.48 \%$ there was absence of other metals like chromium, Nickel, Manganese, Molybdenum \& phosphorus. Ash value was $98.24 \%$, Acid insoluble ash $-1.56 \%$ \& water insoluble ash - 98.44\%.

In Loha bhasma formed contains Iron in the form of Ferrous or in oxide form which are considered to be the most compatible forms of iron supplementation in the body. The rate of the absorption of the iron depends on the fineness of the powder. Bhasma process makes the metal into very minute particles which are easy to absorb. NPST done on the bhasma prepared proved the fineness of the powder by developing the single expanded blue spot.

\section{CONCLUSION}

From the above pharmaceutical and analytical study on the loha bhasma it can be concluded that Loha should undergo samanya shodhana and vishesha shodhana for the proper formation of the bhasma. They help for the purification of iron and make the metal brittle.

Trividha paka process for Loha bhasma enhances the guna of it and reduces the size of the particles facilitating easy absorbtion into the body.

Tests of the ayurvedic parameters of bhasma like Apunarbhava, Nirutta and the Namburi Phased Spot Test proved the fineness of Lohabhasma and also help for the quality standardization of the Loha Bhasma.

\section{Acknowledgements:}

The author is thankful to Sri Venkatesha Engineering Works', Gandhi Square, Mysore for providing the raw material (Iron fillings) and also for the analysis of the Bhasma at different stages.

\section{References}

1. Satpute D. Ashok $1^{\text {st }}$ Chapter Rasendra Sara Sangraha of Shri Gopala Krishna Chaukhamba Krishnadas Academy Varanasi $I^{\text {st }}$ Edition. 2003.

2. Tripathi Indradeva $5^{\text {th }}$ Chapter Rasaratna Samuchaya of Vagbhata Edited by Dr. Kapil Deo Giri 
Chaukamba Sanskrit Bhavan $2^{\text {nd }}$ Edition 2003.

3. Kashinath Shastri. Acharya Sadananda Sharma's Rasa Tarangini translation. $11^{\text {th }}$ Edition. Varanasi; Motilal Banarasi Das; 1994

4. Mishra Gulraja Sharma, Ayurveda Prakasha of Sri Upadhyaya Madhava. $2^{\text {nd }}$ Edition. Varanasi; Chakumba Publication; 1999.

5. Chandrabhushan Jah. Ayurvediya Rasashastra. $13^{\text {th }}$ Edition. Varanasi; Chaukamba Orientalia; 2003.

6. Anonymous. The Ayurvedic Pharmacopeia of India Vol. I, II \& III. First English Edition. New Delhi; CCRAS; 2001.

7. Mishra Sidhinandan. Acharya Bhatta Yashodhara's Rasa Prakasha Sudhakara translation. $2^{\text {nd }}$ Edition. Varnasi, Chaukhambha Orientalia; 1998.

8. Acharya Bindu. Rasa Paddhathi. Varanasi; Chaukhambha Orientalia; 1987.
9. Mukerji Kaviraj Bhudeb. Rasa Jala Nidhi Vol. II. Avani Prakashana; 1984.

10. Mishra Siddhinandana. Acharya Somadeva's Rasendra Choodamani. Translation. $2^{\text {nd }}$ Edition. Varnasi; Chaukhambha Orientalia; 1999.

11. Vaidya Ramprasad. Rasendra Purana. Ganga Vishnu Shri Krishnadas; 1983.

12. Namburi Hanumantha Rao. Manual of Namburi phased spot test. Vijayawada; Namburi publications; 1977.

13. Pandit Chaube Datta Ram. Brihat Rasa Raja Sundara. $3^{\text {rd }}$ Edition. Varanasi; Chaukambha Orientalia; 2000.

14. Gribble CD. Rutley's Elements of Mineralogy. $27^{\text {th }}$ Edition. New Delhi; CBS Publishers \& Distributors.

15. D. Shripathi Rao. A Text Book of Chemistry. $1^{\text {st }}$ Edition. Mangalore; Deepa Publication; 1996. 


\section{Raw sample of $\mathrm{Fe}$}

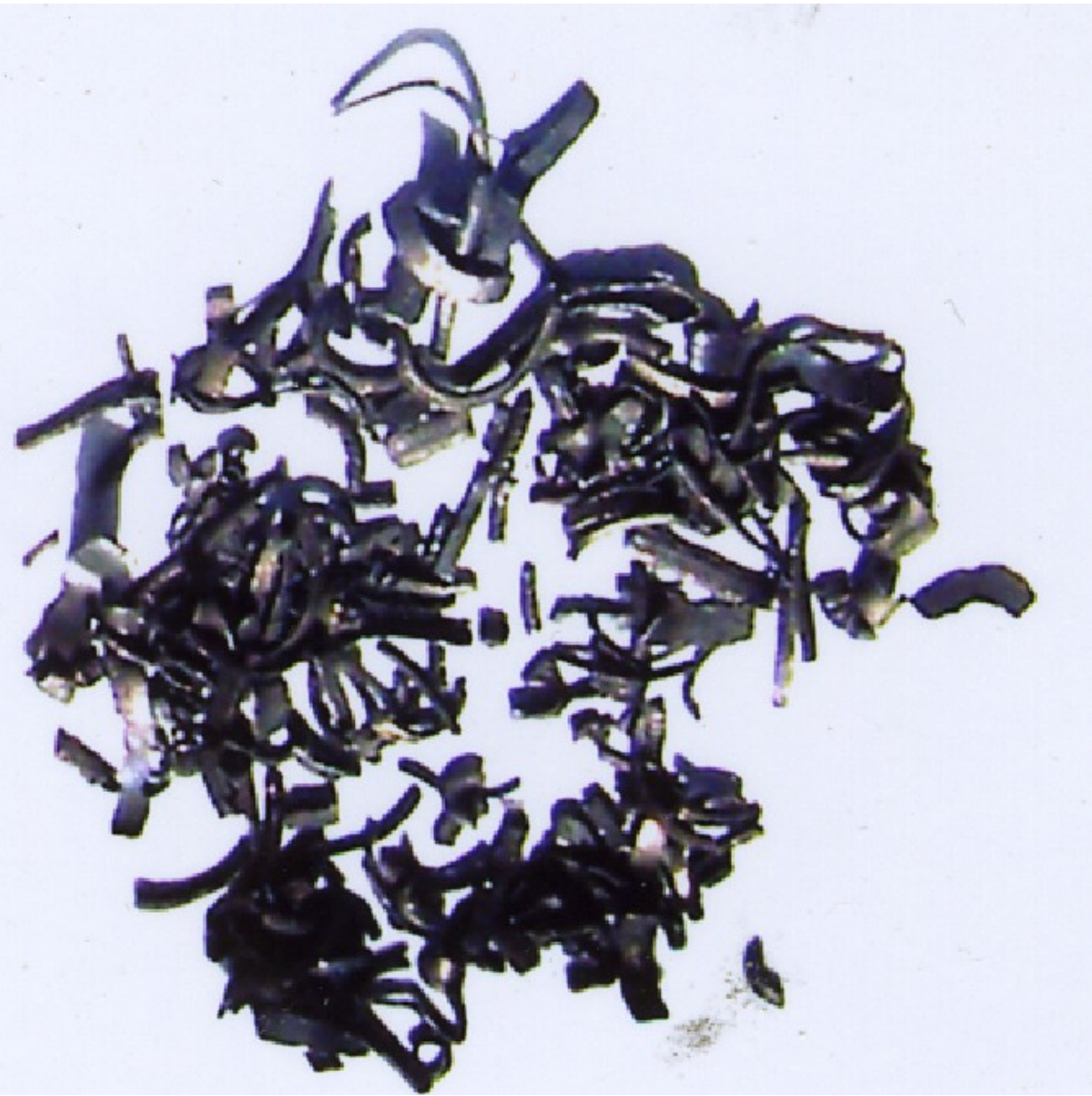

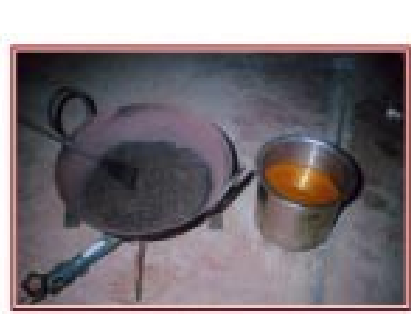

Nirvapa with Taila

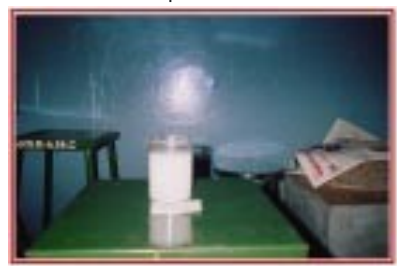

Nirvapa with Kanj

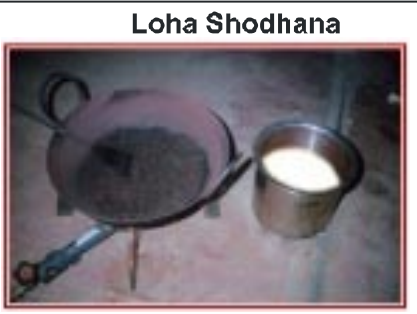

Nirvapa with Takra

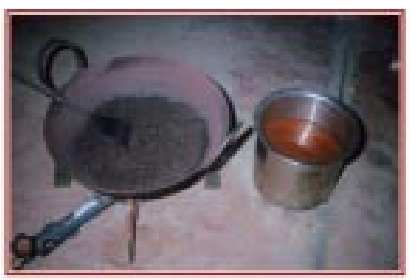

Nirvapa with Kullatha Kwatha

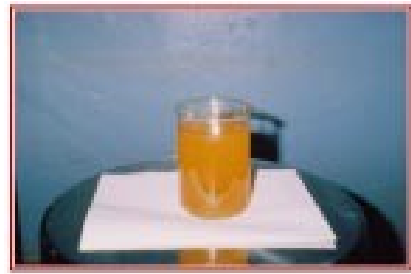

Nirvapa with Gomutra

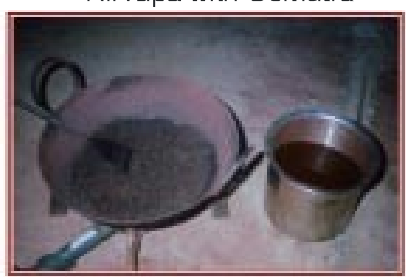

Nirvapa with Triphala Kwatha 


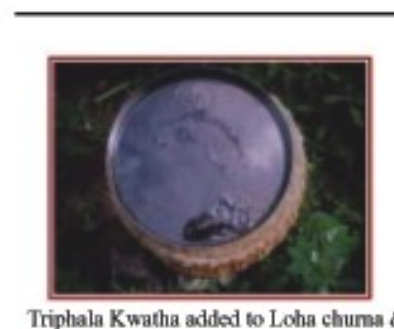

Triphala Kwaths added to Loha chuma \& kept under Sun for evaporation of Kwatha

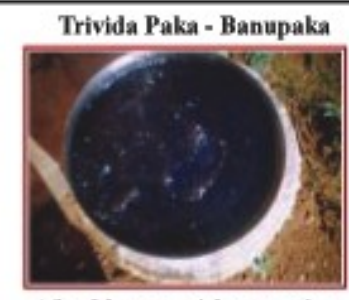

After 3 hours partial evaporation

of Kwatha

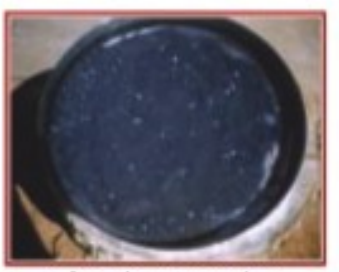

After 5 hours complete evaporation of Triphala Kwatha

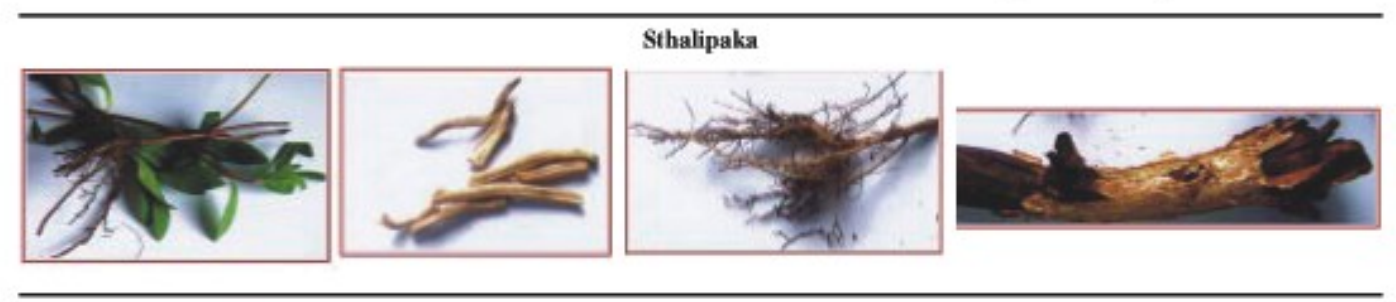

Puta Paka
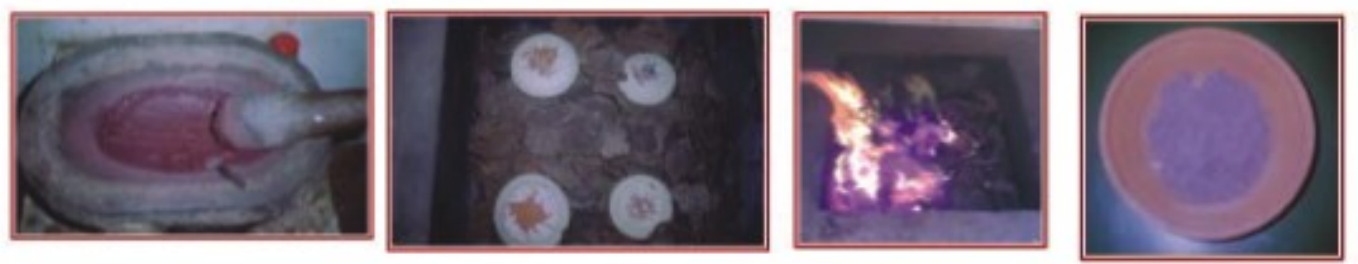

Apunathhava legt
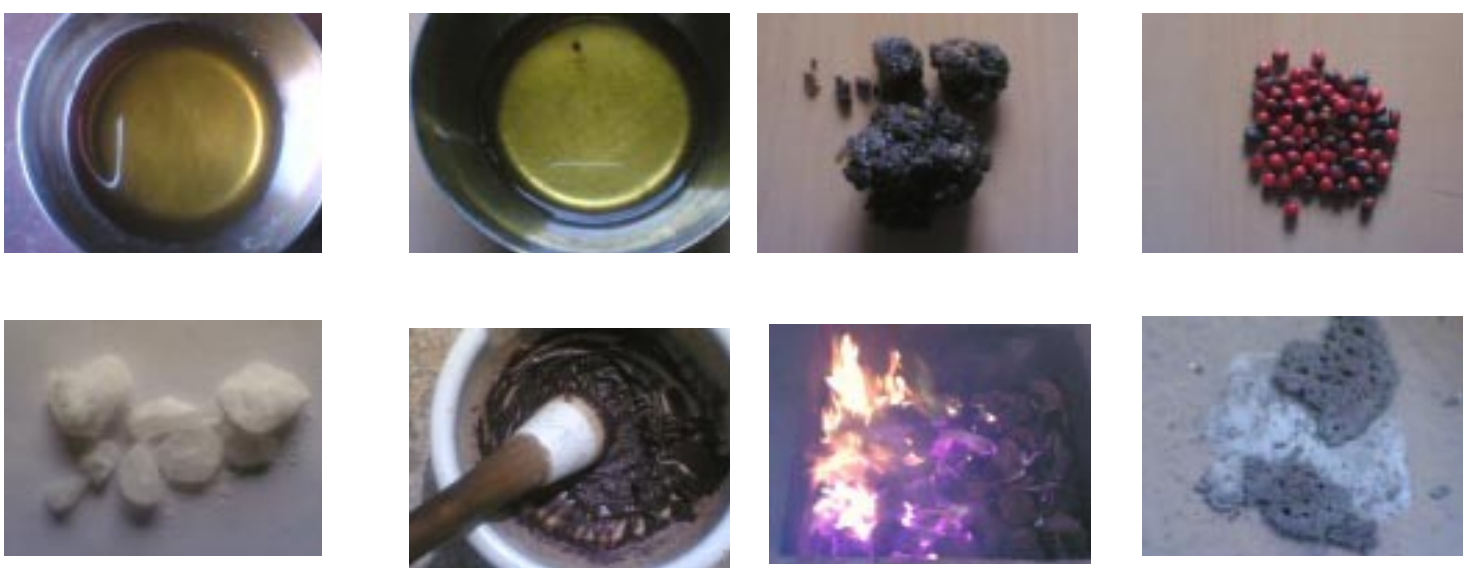


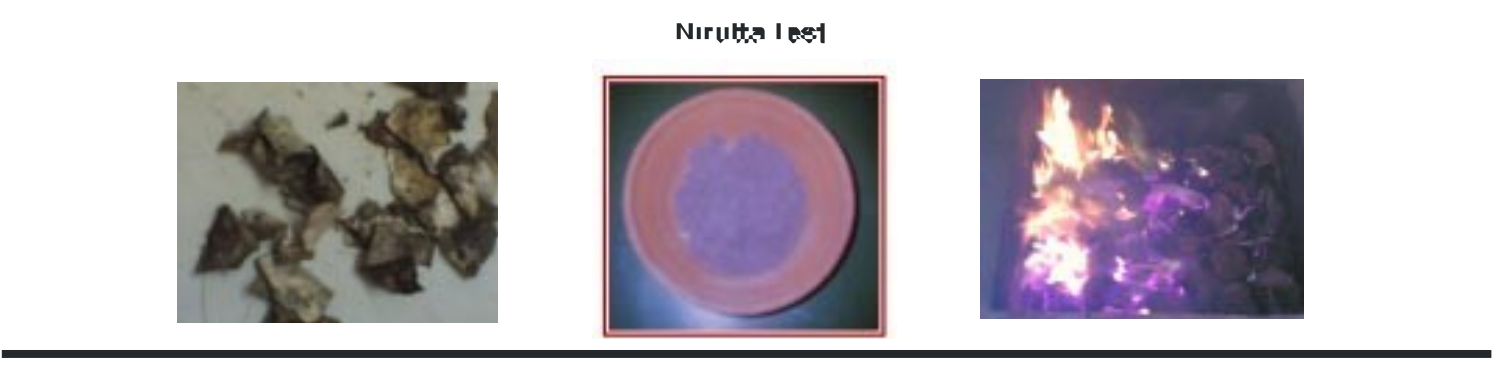

Fhysleal lest
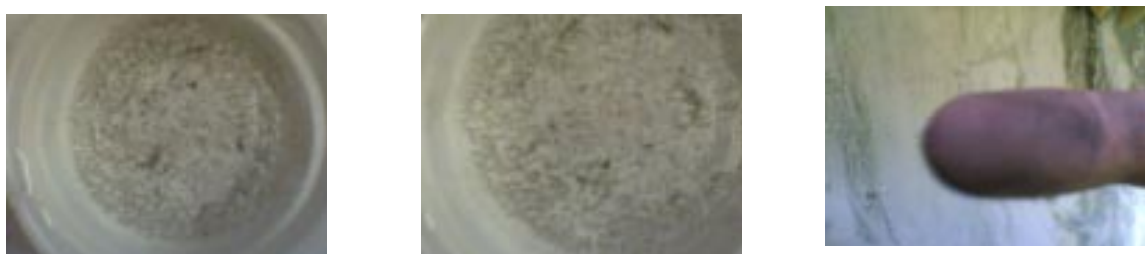

NPST

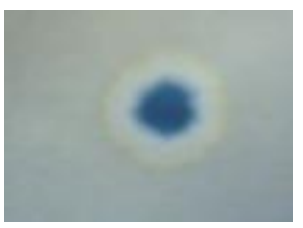

$* * * * * *$ 